\title{
THE INTERNATIONAL BUSINESS ENVIRONMENT AND THE ISSUE OF RISKS FOR INTERNATIONAL BUSINESSES
}

\author{
Professor PhD Ioan Rotariu, West University of Timişoara, \\ e-mail: ioan.rotariu@feaa.uvt.ro \\ Junior Assistant PhD Student Emoke-Szidonia Feder, West University \\ of Timişoara,e-mail: emoke.feder@feaa.uvt.ro
}

\begin{abstract}
The business environment within commercial transactions are realized is highly dynamic and in continuous transformation, firms being under its scope of impact. The knowledge, understanding and analyses of the business environment, it's anatomy and functioning mechanism represents the starting-point in identifying opportunities and threats, necessary to decision making, process carrying the mark of three situations in which the decedents may found themselves: decisions taken in certainty conditions, decisions taken in uncertainty conditions, decisions taken in risk conditions. The process of decision, in internal and mainly international transactions must be approached at two levels: at macroeconomic level, as result of a multitude of political and economical interdependencies, decisional act being confronted with country level risk, and at microeconomic level in order to adopt decisions interfered by firm level specific risk.
\end{abstract}

Keywords: international business environment, certainty, uncertainty, risk

JEL Codes: F4, F41.

\section{Senses and meanings of the international business environment concept}

From historical perspective, the unrolling of the international economical businesses, possesses both features of continuity and time and spatial specifies. Components of continuity refers to strategic goals and objectives for which businesses are initiated, and the specificity elements regarding the ,actors" which unroll the business, and also the context of the trace of these businesses, known as the time and space specific „business environment”.

To start or unroll a business does not seem to be very complicate. Problems and issues begin to appear in the moment when we strive for its success, to be recognized by the target consumers in order to cover needs and bring return to the entrepreneur. The entrepreneur spirit is nice and exciting, but indicates a series of risks and responsibilities, but in the euphoria of the moment they lost from sight crucial elements for the success of the firm. One of these is represented by the limited knowledge of the „business environment” in which it acts.

Any firm, in order to ground its decision to allocate resources, needs to focalize its attention upon the business environment in which it acts or propose to act.

In order to answer to the question: What represents this ,existing reality” denoted by the „business environment” concept?, a first anchor point is offered by the general environment term, which designate "the surrounding environment in which beings and things exists, but also the world in the middle somebody lives as milieu" [DEX, 1984, p. 536].

A more punctual perspective represents „Environment, as the overall uncontrollable of forces, to which the enterprise must adapt its policies and it is made of the participants and external forces which influences upon the enterprises' possibilities to develop and maintain gainful transactions [Ph. Kotler, 1998, p. 178]. 
A diverse approach perceive that „The environment factors, after origin and role, may be classified in: natural environment factors as: soil, climate, water, forest, etc., conditions; all of these representing the primary material support of existence and biological-economical-social life; and artificial factors: represented by the human created conditions in order to ameliorate life conditions and their multilateral development [A. Iancu, 2000, p. 20].

From the perspective of the firms, the environment consists of: ,the external and internal market, in its framework enterprises offering reciprocal goods, services, works, information, etc., collaborate and many times confront by entering in competition" [E. Novac, 1999, p. 32].

A next approach to retain is that „External environment is represented by main forces outside the organization with high impact potential on influencing the success of previously delivered goods and services" [Gh. Ionescu, 1996, p. 20]. Thereby, the external environment of the organization is made of two segments. The mega environment or the general external environment of the firm, reflecting the main conditions and the trends from the society in which it acts, also incorporates the international approach. The assignment environment, formed by the specific elements with which the firm interacts in the process of business enrollment, comprehends: consumers, clients, competitors, suppliers, the work-force market, public agencies.

In conformity with the definitions from the economic literature, elements to retain refer to the complexity of the problematic, the multitude of the elements taken in consideration and the temporal and spatial aspects of the approach. The accurate and scientifically rigorous definition of the „environment” in general and „,business environment” in particular, may be ease by using the systems approach, which permits a logic and coherent way to interpret, a whole manner, but not as the simple sum of the components, but as a resulting system and manifesting form of the interrelation between its structural elements, and the separation of its own dynamics, motion and becoming of each and every component. Also on methodological level, in the knowledge of economic phenomena, hypotheses and theory represents the arsenal of tools for systematizations, organization, process and interpretation of the primary knowledge obtained through observation, law-like generalization and unified through inductive synthesis.

Based upon these methodological principles, a proposed definition refers to the general environment as result and form of manifestation of the interdependence between its constructive elements: territorial complex, result of a slow and toilsome synthesis, in which are combined elements of relief, geological structure, subsoil resources, waters, climate conditions, soil, vegetation and fauna, all constituting the natural framework of the material and spiritual life unfolding of a human community. On the structural fond of these elements, has been formed the social (social-institutional) environment, as the ensemble of economical, legal, political, cultural and religious elements and structures, which forms the superstructure necessary for the activities of the determined human community, on a certain level of its historical development, elements in permanent change, modeled by the aspiration and interest of the human collectivity and of those who hold the power.

Consequently, between the constitutive elements of the system, which forms in general the environment, and particularly the business environment, there exist causal type relations, each and every one conditioning and being conditioned by the other. The modification, under the influence of some factors, of one of the elements will determine the modification of other elements conditioned by the first, but the system as a whole being in a relative equilibrium.

All these coordinates forms the economic environment of the businesses, a complex reality, being in a continuous motion, reseat, with dynamic features, characterized through a relative stability, marked by favorable and unfavorable conjuncture.

In the context of the essential processes which determines the motion of the whole global economy's system, represented by regional economic integration and globalization, it is ascertained to emphasize the nations economical and political interdependencies based on the process of motion and self-formation of the national economies. Hence, we associate the concept of environment with 
the relative homogenous segments at the level of national economies, regional spaces - integrated or not -, or the whole global economy system.

For a firm or an economic agent, may be affirmed that, its business environment is compounded by those components and factors from the outside of the organization, which represents for this opportunities, but also threats. We make a distinction between national or domestic environment of the organization and the international business environment, in which the problems are the same, but differs the way of analyze and the capacity to adapt to the existing limitations.

In this paper will focus on the international business environment. The globalization of businesses and markets led to the appearance of the global business environment, which is concerned about the context of the international commercial transaction enrollment on the ground on the depth of the global work division and the multiplication of global economy fluxes and circuits realization.

Regarding the global environment, the problems and issues receive a higher complexity, of risk and uncertainty, because we don't have to deal with a known, familiar environment from the national space, but rather with an international environment, in which manifests other factors too than from the original space of the firm, hardly detectable and controllable ones.

\section{Certainty, uncertainty, risk - features of the business environment}

The economical theory and the practice demonstrated that, an essential attribute of the managerial activity is represented by the decision adoption, force founded in all management functions; which means to elect from a variety of possible actions, taking in consideration also the business environment and the within existing conjuncture, that one, which is considered as being the most rewarding in order to achieve the proposed objectives.

An international business is carried on in extremely diverse external environments, and in variable conjuncture conditions. The performance managers are those who have the capacity to fructify the favorable opportunities and when they confront with unfavorable ones to limit as much as possible the losses. From this point of view, the adopted short or long run decisions, for the moment carries the mark of three situations, in which the decedents may found themselves: decisions taken in certainty conditions, decisions taken in uncertainty conditions, decisions taken in risk conditions.

Under the impulse of the need of conceptual synthesizes and practical operability, there exists the tendency to define the three statuses as concise and relevant. The adopted optic was mainly influenced by the work of Dudian [M. Dudian, 1999, p. 1], in the sense of capturing the successive stages of conceptualization of the terms, in time, space and approach perspective.

\section{Certainty}

The steps in order to define the status of certainty in business, starts from a rhetoric question: from the multitude of uncertainties that accompanies our existence as human beings can we identify also certainty? In the process of scientific knowledge, the historical approach is uncontestable.

In its specific perception forms, the state and need of absolute certainty founds its origins from the appearance of the mankind and of first human communities. The fear from natural catastrophes, illness and death, led to the certainty of founding a support. This support was found in religion, based on fear and the image of supernatural beings existence, gods, which have the power to decide upon the individuals' fate and destiny.

In order to obtain of any kind of certainty, that nothing bad won't happen, through diverse forms of acts and sacrifices, the primitive humans believed that the could favorably influence the 
state of spirit of these supernatural beings. Consequently, this state of certainty was a conditioned one.

Next step was represented by the need to distinguish between good and bad, to know with certainty what is or isn't moral. In this way appeared the faith in God. This is one of providence, he is who decide, protect, repay and punish. It has appeared a new gradate for the concept of certainty. Nothing is randomly, but decided of God, as repay for the acts of people. We can ascertain that the dependency is replaced with interdependency. The divine decision is determined by the individual moral conduct and not by the material sacrifices.

Specific gradates, relieved by the certainty approach, prom religious perspective, the idea of some causality reports from cause to effect is withheld. The causality report, having its pylon in religion, is founded also in philosophy. Thus Greek philosophers affirmed that, with the exception of the Primary Cause, any other thing is of cause-effect type. Differenced by them, the antic Asian cultures have never developed the idea of causality.

The positive science approach, and mainly of the mechanics, were not able and can't give a trenchant answer to the relation determinism and indeterminism. The discovery of quantum phenomenon re-launched the controversy. To causality was opposed again by indeterminism, which affirms that in nature there is nothing besides induced hazard, which existence is determined without any trace of doubt. The quantum physics proved that, in nature there occurs random processes and phenomena, which are not submitted to cause-effect type regularity.

Certainty in business. In the conditions of private property and existence of market economy, liberty of economical initiative is the result of a well defined motive and goal. Because, any action supposes length, between the moment of decision adoption and the manifestation of its effects, there may appear influences which determine the sense of motion, to ascertain if we act or not in a status of certainty. From this perspective, we appreciate that in businesses, including the international ones, there exists and manifests the status of certainty.

Certainty represents that status, in which the decedent knows in the moment of taking the decision with absolute confidence the consequences of the adoption of an alternative from the existing given variants. This affirmation can be argued in particular cases, not generally.

\section{Uncertainty}

Even if in the domain of the businesses can be identified situations of certainty, in the most cases, generally the human behavior and consequently the economic one, does not submit to certain regularities, but rather they are uncertain, unforeseeable. In such a context of reality perception, scientific investigations were oriented towards the elaboration of economical models based on uncertainty.

The forerunner of this approach is the classical school. The most important element to keep in mind about uncertainty is that is based on the state of certainty. Hence classical understood under the concept of uncertainty, a probabilistic type certain future.

The introduction of probabilistic type calculations are made from two points of view: objective and subjective probability, having common components, but also meaningful differentiations.

The objective probabilistic approach starts from calculations regard what will happen in the future, from the perspective what has happened in the past. In this way, future events can be anticipated probabilistically. The decedent has the possibility to choose, from the perspective of the past, a more advantageous alternative rather than other one, because of the randomly game. In classic point of view, this logic does not guarantee the absolute success, only a greater possibility of success.

What is the case of the irreproducible events through statistical series observation? The question receives more answers in the time. 
Such like this appeared the subjective probabilistic interpretation. In conformity with this, the interpretation of future events, not only them which results from experience, rather in subjective perceptions of the decedent. Through subjective probability there is understood a prediction representing the level of trust given by a person to anticipation. The estimation is pure personally and presumes, in order to have a sense, an implicit rationality from the side of whom realizes it.

A try of linkage between objective and subjective probability was made by Keynes, through which was named logical probabilistic, grounded on both experience and individual interpretation. He defined a probabilistic relation, or argument, which characterize the way in which a person interprets the available information from the surrounding world.

In order to clarify the concept of logical probability, we consider two affirmations, A and B, and between there is an intuitive linkage, but can't be described for sure certainty the nature of this relation. So, let $\mathrm{P}$ be the estimation of the probability relation between $\mathrm{A}$ and $\mathrm{B}, \mathrm{P}=\mathrm{A} / \mathrm{B}$. If $\mathrm{P}$ can be evaluated numerically, based on a series of statistical data, will mean that we refer to the objective probability from the classical thought. The same thing will happen, if through continuous information assimilation, subjective probability equals one, becoming certain.

From the Keynesian point of view, in both cases we can't talk of uncertainty, because to the relation between $\mathrm{A}$ and $\mathrm{B}$, there can be attached a numeric probability. If a sequence of events can be foreseen with the help of numeric probability, than future will remain probabilistically foreseeable and the place of uncertainty is taken by risk. Unlike the uncertainty, risk is characterized by the probability to describe a probability law for accounted results waited to be obtained after the action.

Incertitude appears only when the nature of the probability relation remain unknown. In order to speak about uncertainty, must be concomitantly united the next conditions: $P$ can't be numerically described, because there is no relation of any kind, which could allow the numeric calculation of the probability. After Keynes, in economics and mainly in the domain of investments, the majority of the situations are uncertainty.

Confronted with uncertainty and risk, economic agents must elaborate forecasts based on own anticipation. In classical vision based on risk, anticipations are rational ones, taken upon perfect information supplied by the market. From Keynesian point of view, besides rational behavior there exists a conventional behavior too, adopted in conditions of uncertainty reduced to risk. In such conditions, individuals are forced to imitate the others in their options and choices. Shortly, the elaborated progressive anticipations are confronted between them, changed rapidly as function of certain information. As next step, the certain information will arrive together with an „existing reality", as an outside benchmark named convention.

The vision of Keynes over uncertainty is similar to the Austrian subjectivism, in which uncertainty is a radical one, synonym with ignorance. The Austrian subjectivism is estranged from Keynes, remaining a purely individualistic theory. In conformity with this theory, economy is composed of a multitude of independent and reunited individual actions, through processing imperfect information, hardly and difficultly supplied by the market. Anticipations are purely subjective, and the market remains the only one mechanism to merge them, but this will never lead to an emergent effect.

Resuming the points of views, the literature regarding uncertainty state that:

- The classical school reduces incertitude to risk. The market supplies information to the economic agents, presumptive perfect ones, which permits to adopt alternative actions with the highest probability to be good or best.

- The Keynesian uncertainty adds to the market mechanism a conventional behavior, as necessary instrument to a better understanding of anticipations.

- Austrian subjectivism considers the universal market mechanism, impossible to avoid, of which collide all individuals confronted with absolute uncertainty. 
Regards our position, we make a difference between certainty, uncertainty and risk. We join the opinion of which define in essence uncertainty as that situation or state, in which the decedent knows in the moment of the decision adoption, the situation and problems, with which he will confront in the future following the moment of his decision, but does not know the probability of their manifestation and mainly, the obtained results, grounded on diverse acceptable alternatives.

\section{Risks}

Nor the definition of this problem is simple or without controversies. The first problem is that risk is situated in the perimeter of uncertainty and from here follow the question: What kind of uncertainty presumes risk?

As starting point, the notion of risk may suggest the idea that it is about an uncertainty reduces to risk, and so appears the possibility to express numeric the probability due to risk.

In such a problematic context, as first step, risk is represented as the situation in which the decedent does not knows with precision the results of a solution, but anticipates the probability with which various effects will manifest. Problematically, it is marked a business flux: who assumes a higher risk may win more or loose more; who assumes a lower risk may win less but also can loose less. The problem is option and choice of one or another alternative.

Taking in consideration, that the most part of the decisions taken at internal or international level are grounded and applied in practice in conditions of uncertainty and risk based environment; the problems regarding risk can be seen and analyzed from more point of views.

With the whole diversity of expressed opinions, the reference domain takes in consideration three aspects: the definition of risk, classification of risks, and way of attenuation of the negative effects of the appearance risks.

Regarding the definition of the concept, we take in consideration the further opinions from the specialty economic literature.

At the first sight, a risk represents ,the possibility to obtain favorable or unfavorable results in a future action expressed in probabilistic terms" [A. Puiu, 1997, p. 303]. Approached in probabilistic terms, the results and effects of a process or decision can be appreciated a priori, through deduction, or aporteori through empiric measures. In the case of a priori method, the decedent establishes the probability of appearance of a phenomenon through logical deduction, without being needed to make appeal to the past experience. The empirical measuring is based on the registered experience regarding the form of the past data.

In order to be ale to establish the probability of appearance of a phenomenon, it is necessary to carry out the conditions of representative number of observations in order to guarantee stability, the number of iterations in the analyzed sample and the independency of its appearances. Beginning with these conditions, the probability of appearance of a process or phenomenon can be calculated, and the plausibility of result may be considered as a risk.

Another opinion shows that, „economic risk represents an alternative - the other being the chance- of the finalizing conditions of a commercial or financial business" [Gh. Ciobanu, 2004, p. 249]. Therefore, risk is cause of unfavorable results, what can materialize in additional costs, losses, the impossibility to turn to account of the favorable, but uncertain conjuncture. The chance is the factor which make possible to obtain or amplify some favorable results.

Both alternatives - risk and chance - are based on objective or subjective factors and causes, the majority foreseeable with a given level of precision. The chance is the wanted alternative, but risks must to be known and evaluated before, than established necessary protection measures. There exist some other explications too: , Risks represents the possibility to reach danger, to have to confront a trouble or support damage, a possible danger. To risk means to take in peril your life, honor, to expose to a possible danger, to participate to an unsure action regarding luck, to dare, to 
venture. The term risky is used when it is about a situation or action full of risks, exposed to danger, unsure, perilous" [DEX, 1975, p. 809].

Risk can also be defined as ,the possibility of appearance of a loss in the economical business (export, import, cooperation), as consequence of realized unforeseeable events and phenomena" [M. Negruş, 1986, p. 62].

From legal perspective, „risks, in international economical exchanges, represents prejudges determined by fortuitously circumstances. There are distinguished: risks of things, contractual risks, commercial risks and assured risks" [B. Ştefănescu, 1983, p. 317].

In the same opinion, commercial risks are patrimonial consequences of tardy or inadequate execution or non-execution of an obligation stipulated in an international commercial contract, for which the prejudged creditor can't call to book the debtor.

Commercial risks can be determined by phenomena with economical nature: as the nonexecution of the delivery or the price payment obligation because the bankruptcy of the debtor; with political nature: the blockage or closed of boundaries of the debtors' country; or natural phenomena: as earthquake, flood; phenomena interfered between the moment of signing the contract and till the expiration of the obligation, of which put back totally or partially the execution of the contract.

A more particular case, the currency exchange rate risk, refers to the possibility to register losses or gains from an export-import transaction or from any other kind of action which implies external payments, because of the depreciation or appreciation of the contract currency.

This is defined by some authors as, the probability to produce loses from the modification of the exchange rate, so as being an average value; and by others as the concept or fluctuations, reflecting the uncertainty to produce modifications in the exchange rate and value of this modification.

Because the modification of the exchange rate may produce for the same economic agent, a loss or a gain, the currency exchange rate risk is considered as part of the speculative risks, not as member of the pure risk category which one produced realizes only losses. The measure of the currency exchange rate risk is known as exposure to risks.

As our opinion, we appreciate that risk can't be interpreted in exclusive terms of ,gain” and „loss”, „favorable” or „unfavorable” situation.

The decision in risk conditions, means that the decedent, in the moment of decision adoption, based on past experiences, so upon confirmed statistical laws; or based on anticipations, by not taking in consideration what happened in the past; or by combining them, will know the decisional alternatives. What he did not knows and regarding this he assumes risk, refers to the consequence of the alternatives, as being probabilistic associations.

To choose and adopt a decision starts from the premise that it has at least three alternatives: gain, loss, gain and loss. The interpretation of one from the three alternatives, the waiting, appears in close correlation with the firms' situation in the moment of decision adoption and also with the business environment of the firm in which this acts.

Decision in the condition of uncertainty, presents important gradates towards the risk conditions. In uncertainty conditions, who adopt the decision ,, does not know all the alternatives, can't identify the associated probabilities to the alternatives which he knows, and does not know the consequences that could have any of the known alternatives" [I. Popa, 1999, p. 182].

In these conditions, the informational system has a primary role in order to assure to the decisional process an essentially logic approach. The experience in adopting decisions and in finding solutions, are the most important competencies must possessed by a manager who makes decisions in uncertainty and under risk conditions.

The decisional process for internal and mainly international transactions, in the conditions of risk, must be divided on two levels. On the first hand, at macroeconomic level, as result and manifestation of a multitude of political and economical interdependencies, in this case the 
decisional act and process is confronted with country risk. On the other hand, at microeconomic level, by referring to the firm, where in the adoption of the decision, interfere the firm specific risk.

\section{Conclusions}

The actual period is characterized by an extremely strong turbulence of the international business environment. Present article evidences with arguments the main motives for the scanning of the international business environment is the initial stage of any business process.

Another conclusion refers to the emphasize on risk and uncertainty from the whole scale of existing threats. The developed conceptual approaches enclose the fate to prepare the contractual and non-contractual solution finding in order to avoid the losses thanks to a situation of risk and uncertainty.

\section{References:}

1. Bradley F. - Marketing internaţional, Editura Teora, Bucureşti, 2001;

2. Ciobanu Gh. - Tranzacții economice internaționale, Editura Imprimeria „Ardealul”, Cluj - Napoca, 2004;

3. Dudian Monica - Evaluarea riscului de țară, Editura All Beck, Bucureşti, 1999;

4. Iancu A. - Politica şi economia. Repere ale unui sistem economic perfect, Editura Expert, Bucureşti, 2000;

5. Ionescu Gh. - Dimensiunile culturale ale managementului, Editura Economică, Bucureşti, 1996;

6. Kotler Ph. - Principiile marketingului, Editura Teora, București, 1998;

7. Negruş Mariana - Mijloace şi modalităț de plată internaționale, Editura Academiei R.S.R., Bucureşti,1986;

8. Novac Emilia, Abrudan Denisa - Management, Editura Mirton, Timişoara, 1999;

9. Ştefănescu B., Rucăreanu I. - Dreptul comerțului internaţional, Editura Didactică şi Pedagogică, 1983;

10. Popa I. - Tranzacții comerciale internaționale, Editura Economică, Bucureşti, 1997;

11. Popa I., Filip R. - Management internațional, Editura Economică, Bucureşti, 1999

12. Puiu Al. - Management în afaceri economice internaționale, Editura Independența Economică, Brăila, 1999;

13. Rotariu I. (coord.) - Managementul tranzacțiilor economice internaționale şi strategia competitivității, Editura Mirton, Timişoara, 2001;

14. ***, Academia Română, Institutul de Lingvistică „Iorgu Iordan”, Dicționarul explicativ al limbii române, Editura Academiei, 1984, 1975. 